\title{
Recenzja
}

\section{O. W. Skripniuk, Konstytucijne prawo Ukrainy. Akademicznyj kurs. In Jure, Kijów 2010, ss. 670}

Rosnącemu zapotrzebowaniu na podstawowe wiadomości o najważniejszych gałęziach prawa i dyscyplinach nauk prawnych starają się wyjść naprzeciw poszczególne wydawnictwa $\mathrm{w}$ różnych państwach, publikując podręczniki dotyczące danej dziedziny prawa w ich kraju. Z natury rzeczy obejmują one w sposób ogólny najbardziej rudymentarne elementy danej dziedziny prawa. Osobie, która poszukiwałaby bardziej pogłębionych rozważań, pozostają w praktyce nie prawnicze skrypty akademickie, ale komentarze ustaw i książki specjalistyczne. Pisane są one jednak językiem trudniejszym, skierowanym nie zawsze do studentów prawa, lecz raczej do wykształconych prawników, co utrudnia odbiór zawartych w nich treści przez osoby, które jeszcze nie przyswoiły sobie języka prawniczego i posiadają zaledwie wstępną wiedzę prawniczą.

W opisanej sytuacji na pochwałę zasługują inicjatywy wydawnicze mające na celu przybliżenie w możliwie najbardziej przystępnej i zwięzłej formie dorobku niektórych dziedzin prawa poprzez ograniczenie zakresu rozważań do niezbędnego dla danej dyscypliny nauki prawa minimum. Należy do nich recenzowana praca O. W. Skripniuka. Autor wychodzi z założenia, że specyfika prawa konstytucyjnego powoduje, że z dorobku nauki tego prawa korzystają przedstawiciele innych dyscyplin. Znajomość podstawowych zasad i instytucji ustroju państwowego pozwala im na zrozumienie procesów tworzenia prawa, sensu norm prawnych stanowiących przedmiot ich badań oraz na lepsze rozeznanie w zakresie ich stosowania. Stara się więc, aby jego książka stanowiła rozwinięty podręcznik nie tylko dla studentów studiów prawniczych, ale też, jak pisze Autor w przedmowie (s. 3), „dla prawników, polityków oraz urzędników państwowych, a także dla wszystkich bez wyjątku obywateli”. Założenie to udało się Autorowi dobrze zrealizować, gdyż książka pisana jest przystępnym językiem. Autor nie zapomina, że pisze dla czytelnika posiadającego jedynie znajomość podstawowych pojęć prawni- 
czych. Dlatego też stara się unikać niekiedy efektywnych, ale trudnych do zrozumienia zwrotów prawniczych, a tym bardziej rozbudowanych figur retorycznych. W efekcie cały podręcznik napisany jest językiem łatwym w odbiorze.

Tematyka podręcznika O. W. Skripniuka jest przy tym w pełni zgodna z planem i programem studiów prawniczych na Ukrainie. Kończący recenzowaną pracę, liczący 270 pozycji, wykaz rekomendowanej przez Autora prawniczej literatury ukraińskiej (s. 647-664) pozwala czytelnikom zainteresowanym szerzej jakimś zagadnieniem na szybkie znalezienie literatury uzupełniającej treści podręcznika. Wszystko to sprawia, że studentom łatwo jest z niego nie tylko korzystać, ale też samodzielnie studiować poszczególne zagadnienia, szukając ich rozszerzenia w podanej przez Autora literaturze dodatkowej. Realizacji celu dydaktycznego pracy służą zamieszczane na końcu każdego rozdziału pytania kontrolne i tematy referatów.

Sam spis treści składa się z dwóch części - ogólnej i szczegółowej. Obejmują one dwadzieścia jeden rozdziałów podzielonych na mniejsze jednostki. Ma to stanowić dla Czytelnika pomoc w znalezieniu interesującego go wątku. Tym bardziej, że tytułu rozdziałów i podrozdziałów mają charakter hasłowy, łatwo pozwalający odczytać ich zawartość merytoryczną. Podnosi to wartość dydaktyczną i praktyczną recenzowanej książki.

Układ recenzowanej pracy jest logiczny i oparty o tradycyjnie stosowany w nauce prawa konstytucyjnego schemat. Na samym początku w części pierwszej o charakterze ogólnym i teoretycznym są więc rozdziały poświęcone miejscu prawa konstytucyjnego w systemie prawa, jego cechom szczególnym, jego podmiotom i nauce prawa konstytucyjnego. Autor słusznie dostrzega (s. 7), że w większości współczesnych państw można wyodrębnić jedną dziedzinę, której przedmiotem regulacji są podstawowe instytucje oraz zasady ustroju politycznego i społeczno-gospodarczego państwa. Jej normy określają pozycję państwa w stosunkach zewnętrznych i wewnętrznych, podmiot władzy w państwie i formy jej sprawowania przez suwerena, status jednostki w państwie (obywatelstwo, prawa, wolności i obowiązki jednostki), zasady organizacji i funkcjonowania organów państwowych oraz relacje między nimi, a także zasady tworzenia prawa. O ile wyróżnienie tej gałęzi prawa nie rodzi żadnych problemów, o tyle jej nazwa jest przedmiotem dyskusji i Autor w rozdz. I, omawiając ją zarówno na gruncie ukraińskim, 
jak i w ujęciu komparatystycznym podaje najczęściej stosowane określenia, przychylając się ku nazwie „prawo konstytucyjne”.

Z punktu widzenia czytelnika zagranicznego szczególnie interesujący jest mieszczący się w pierwszej części omawianej pracy rozdział 7 (s. 153-167) zatytułowany „Konstytucyjne prawo Ukrainy a konstytucyjne prawo Unii Europejskiej”. Autor podkreśla fakt bazowania obowiązującej konstytucji Ukrainy na tradycjach „klasycznego europejskiego konstytucjonalizmu" (s. 153). Stanowi to zerwanie z okresem radzieckim (s. 154). Wskazuje przy tym, że „w XXI w. Ukraina uznała za priorytet rozwoju swojej polityki zagranicznej kurs na integrację europejską. Realizacja tego kursu zakłada wchodzenie Ukrainy do politycznych, ekonomicznych i wojskowych struktur Unii Europejskiej (UE), adaptację obowiązującego ustawodawstwa Ukrainy do prawodawstwa UE, a z czasem - w akcesję Ukrainy do UE" (s. 154). W obowiązującej Konstytucji Ukrainy brak jest jednak jakiegokolwiek odniesienia do UE i do realizacji tych zadań. Jej art. 9 zawiera jedynie ogólną regulację dotyczącą miejsca umów międzynarodowych w systemie prawnym Ukrainy i zapewnienia ich zgodności z ustawą zasadniczą. W tym kontekście Autor postuluje, aby w trakcie rewizji konstytucji lub uchwalenia nowej zamieścić $\mathrm{w}$ niej postanowienia bezpośrednio związane z procesem harmonizacji prawa ukraińskiego i prawa UE, a w dalszej perspektywie także implementacji prawa UE (s. 155). Jego zdaniem (s. 166-167) nawet $\mathrm{w}$ chwili obecnej ani normy konstytucyjne, ani ustawowe nie stanowią przeszkody dla dokonywania tych zadań. Dobrze, że w rozdziale tym znalazły się też podstawowe wiadomości o samym systemie prawnym UE (co zwłaszcza w obecnej chwili będzie na pewno budzić zainteresowanie Czytelników ukraińskich), gdyż bez nich niektóre fragmenty późniejszych rozważań byłyby może nie w pełni zrozumiałe. Podnosi to wartość poznawczą omawianego podręcznika.

Szczegółowym rozwiązaniom ustrojowym O. W. Skripniuk poświęca drugą część swojej pracy, dzieląc rozważania na dotyczące konstytucyjnego prawa materialnego (s. 187-624) i proceduralnego (s. 625-646). Podział ten nawiązuje do występującego w literaturze prawniczej odróżnienia prawa materialnego od proceduralnego. To pierwsze zawiera normy regulujące stosunki prawne i porządkujące system prawny, a prawo formalne obejmuje normy służące stosowaniu prawa materialnego. 
W prawie konstytucyjnym występują, aczkolwiek w różnej skali, obydwa rodzaje norm. Przewaga norm materialnych skłania zwykle do zaliczenia go do prawa materialnego. Należy jednak zastanowić się nad sensownością wyróżnienia w jego ramach dwóch podsystemów prawnych - prawa konstytucyjnego materialnego i prawa konstytucyjnego formalnego zawierającego normy proceduralne. Ich liczba znacznie rośnie w ostatnich latach, co prowadzi do swoistej „proceduralizacji” prawa konstytucyjnego. Zjawisko to dostrzega również $\mathrm{O}$. W. Skripniuk i w rozdziale poświęconym proceduralnemu prawu konstytucyjnemu omawia poglądy doktryny prawa na temat przesłanek wyróżnienia tej dziedziny prawa konstytucyjnego oraz wskazuje na te źródła ukraińskiego prawa konstytucyjnego, które mają przede wszystkim charakter proceduralny.

Szczegółowe rozważania na temat ustroju Ukrainy otwiera rozdział charakteryzujący konstytucyjne podstawy Ukrainy. W pierwszym jego paragrafie Autor po opartych na szerokiej perspektywie komparatystycznej wywodach dochodzi do wniosku, że dla określenia formy państwa ukraińskiego (rozumianej jako prawnie określony sposób organizacji życia politycznego i społecznego w państwie) należy używać nazwy albo republiki parlamentarno-prezydenckiej, albo prezydencko-parlamentarnej (s. 193). Do jej cech należy - według Autora - wybór prezydenta w wyborach powszechnych lub przez kolegium elektorów (rzadziej przez parlament); szersze niż w republice parlamentarnej kompetencje prezydenta obejmujące uczestnictwo w procesie legislacyjnym, włączając w to prawo weta; kompetencja do wydawania aktów normatywnych o charakterze wykonawczym; powoływanie premiera za zgodą parlamentu. Oprócz Ukrainy do państw, w których występuje ta forma, zalicza: Bułgarię, Polskę, Portugalię i Francję. W rozważaniach na temat formy państwa ukraińskiego O. W. Skripniuk odchodzi od określania tego pojęcia w oparciu o jedną tylko cechę identyfikacyjną, gdyż tak konstruowane definicje nie charakteryzują w pełni stosunków wewnętrznych w państwie. Dlatego też stosuje podejście kompleksowe lepiej oddające charakter ustroju państwowego. Bierze się w nim pod uwagę czynniki społeczne, polityczne, gospodarcze o różnorodnym charakterze i relacje zachodzące między nimi.

W rozdziale na temat konstytucyjnych podstaw Ukrainy O. W. Skripniuk omawia ponadto konstytucyjne zasady ustroju politycznego, funkcje państwa oraz konstytucyjne zasady bezpieczeństwa narodowego i obrony. 
W kolejnych rozdziałach dotyczących oraz imponderabiliów i zasad ustrojowych przedstawione zostają założenia konstytucyjnego porządku Ukrainy (s. 219-260) i jej ustrój (podział) administracyjno-terytorialny (s. 262-280).

Następnie Autor w obszernym rozdziale (s. 281-350) omawia ważną dla każdego obywatela i każdej osoby podległej prawu ukraińskiemu kwestię statusu jednostki (prawa, wolności i obowiązki jednostki) ze szczególnym uwzględnieniem i rozwinięciem przysługujących jej praw politycznych. Łączy się z tymi rozważaniami rozdział o formach demokracji bezpośredniej na Ukrainie (s. 351-389) obejmujący charakterystykę prawa wyborczego oraz omówienie kształtu instytucji referendum. W tym miejscu na uwagę zasługuje ewolucja prawa wyborczego (s. 364) od większościowego systemu wyborczego w wyborach parlamentarnych po odzyskaniu niepodległości, przez system mieszany po system proporcjonalny od 2006 r. Szkoda, że Autor nie wyjaśnia jej przyczyn. Wskazuje za to w podrozdziale poświęconym perspektywom „rozwoju demokracji referendalnej i wyborczej” na Ukrainie (s. 385-387) na rozwiązania służące udoskonaleniu funkcjonowania referendum oraz wyborów.

Trzeci segment szczegółowej części recenzowanej pracy stanowi system organów państwowych (Autor omawia w kolejnych rozdziałach: Radę Najwyższą, Prezydenta, pojęcie organów władzy wykonawczej i gabinet ministrów, Sąd Konstytucyjny, sądy powszechne, prokuraturę) oraz samorząd terytorialny. W poszczególnych rozdziałach nie ogranicza się tylko do zreferowania prawnego kształtu opisywanych instytucji i rozwiązań ustrojowych, ale stara się w poruszanych przez siebie kwestiach przedstawić w sposób zwięzły dorobek nauki prawa konstytucyjnego, nie tylko ukraińskiej, ale w szerszej perspektywie - nauki w państwach demokratycznych. Czyni to przy tym w sposób interesujący bez zbytniej symplifikacji rozważań i spłycania poruszanych zagadnień.

Założenie sformułowane $\mathrm{w}$ podtytule recenzowanej pracy - wykład (kurs) akademicki - udało się Autorowi dobrze zrealizować. Efekt jego wysiłku jest na dobrym poziomie akademickim. Wyszedł nawet chyba poza określony przez siebie zakres adresatów. Jego podręcznik stanowić może nie tylko pomoc dydaktyczną dla studentów prawa, ale również może okazać się przydatny dla prawników na co dzień nie zajmujących się prawem konstytucyjnym i pragnącym przypomnieć sobie jakieś wiadomości podstawowe, a także może być użyteczny dla przedstawicieli zawodów parających się 
na co dzień problematyką prawniczą, jak np. dziennikarze czy politolodzy, poszukujących wyjaśnienia problemów albo tylko chcących zapoznać się ze stanem prawnym w sprawach stanowiących przedmiot debaty publicznej.

Bogusław Banaszak (Uniwersytet Wrocławski) 